\title{
INOVASI PENGEMBANGAN SISTEM INFORMASI PENGELOLAAN PONDOK PESANTREN MANSYAUL MUBTADI'IN BERBASIS WEB
}

\author{
Tito Sugiharto,S.Kom., M.Eng ${ }^{1)}$, Siti Maesyaroh, M.Kom ${ }^{2)}$ \\ 1,2), Teknik Informatika Universitas Kuningan \\ Jl Cut Nyak Dien No 36 A Cijoho Kabupaten Kuningan \\ Email : tito@uniku.ac.id ${ }^{1)}, \underline{\text { siti.maesyaroh@uniku.ac.id }}^{l)}$
}

\begin{abstract}
Abstrak
Permasalahan yang dibahas dalam penelitian ini adalah inovasi pengembangan sistem informasi pengelolaan Pondok Pesantren Mansyaul Mubtadi' in berbasis web. Pada kondisi saat ini, sistem pengelolaan Pondok Pesantren Mansyaul Mubtadi' in masih bersifat tradisional dan manual. Dengan sistem pengelolaan yang masih bersifat tradisional dan manual memunculkan banyak permasalahan, yaitu: sistem rekap data santri masih menggunakan kertas, terjadi penumpukan dokumen dalam ruangan, sulitnya melakukan pencarian data santri, dan pelaporan data yang rumit serta tidak rapih.

Oleh karena itu, inovasi pengembangan sistem informasi pengelolaan Pondok Pesantren Mansyaul Mubtadi' in berbasis web menjadi hal yang sangat dibutuhkan. Dengan adanya sistem informasi tersebut diharapkan dapat mempermudah proses rekap data santri, proses pencarian data, proses dokumentasi data, dan proses pelaporan.

Desain penelitian ini berupa perancangan dan pembuatan sistem informasi pengelolaan Pondok Pesantren Mansyaul Mubtadi' in berbasis web. Subyek dari penelitian ini adalah pengelola dan pengurus Pondok Pesantren Mansyaul Mubtadi'in. Target penelitian yang ingin dicapai adalah adanya inovasi pengembangan sistem informasi dalam hal pengelolaan Pondok Pesantren Mansyaul Mubtadi' in yang menarik, mudah dipahami dan mudah untuk digunakan.

Metodologi yang digunakan dalam penelitian ini adalah RUP (Rational Unified Process). Terdapat empat tahapan dalam penggunaan metodologi RUP ini, yaitu tahapan inception, ellaboration, contruction, dan transition. Model perancangan yang digunakan dalam penelitian ini menggunakan UML (Unified Modelling Language).

Inovasi pengembangan sistem informasi Pondok Pesantren Mansyaul Mubtadi'in ini dapat memberikan solusi bagi permasalahan yang ada dengan melihat pada proses perancangan yang sudah dilakukan sebelumnya. Diharapkan dengan adanya aplikasi ini dapat membantu dalam pengelolaan Pondok Pesantren Mansyaul Mubtadi' in mulai dari proses pendataan santri, proses pencarian data, proses dokumentasi data, dan proses pelaporan.
\end{abstract}

\section{Kata Kunci : Pesantren; Sistem Informasi; RUP; UML; Web}

\begin{abstract}
The problems discussed in this research are the development of web-based information system management in Mansyaul Mubtadi'in Islamic Boarding School. In the current conditions, Mansyaul Mubtadiin's Islamic Boarding School management system is still traditional and manual. With the management system that is still traditional and manual, it raises many problems, namely: the santri data recap system still uses paper, document buildup occurs in the room, the difficulty of conducting santri data searches, and complicated and untidy data reporting.

Therefore, the web-based innovation of the development of the Mansyaul Mubtadiin Islamic Boarding School management information system is very much needed. With the existence of this information system, it is expected to simplify the process of recapitulating the santri data, the process of data searching, the data documentation process, and the reporting process.

The design of this research is the design and manufacture of a web-based Mansyaul Mubtadiin Islamic Boarding School management information system. The subjects of this study were the management and administrators of the Islamic Boarding School Mansyaul Mubtadiin. The research target to be achieved
\end{abstract}


is the innovation of information systems development in terms of management of Mansyaul Mubtadi 'Islamic Boarding School which is interesting, easy to understand and easy to use.

The methodology used in this research is RUP (Rational Unified Process). There are four stages in the use of this RUP methodology, namely the stages of inception, ellaboration, contruction, and transition. The design model used in this study uses UML (Unified Modeling Language).

Innovation development of information systems Mansyaul Mubtadi'in Boarding School can provide a solution for the existing problems by looking at the design process has been done before. It is hoped that this application can help in the management of the Mansyaul Mubtadiin Islamic Boarding School starting from the process of data collection of the santri, the data search process, the data documentation process and the reporting process.

\section{Keywords: Islamic boarding school; Information Systems; RUP; UML; Web}

\section{PENDAHULUAN}

Proses pendidikan dan pengelolaan pondok pesantren baik secara kelembagaan maupun secara substansi telah banyak mengalami perubahan. Pengembangan pondok pesantren bukanlah hal baru, dan hal ini terus dilakukan baik oleh internal pondok pesantren maupun bekerja sama dengan dengan lembaga lain.

Pengelolaan pondok pesantren yang baik akan menghasilkan keluaran yang baik dan berkualitas. Tujuan didirikannya sebuah pondok pesantren adalah untuk memberikan pelajaran dan wawasan tentang ilmu agama islam kepada semua santrinya untuk menjadi pegangan baik di dunia maupun di akherat. Pondok pesantren di Indonesia sudah mulai banyak yang menyesuaikan diri dengan perkembangan teknologi informasi, namun ada juga pondok pesantren yang menutup diri dari pengaruh perkembangan teknologi informasi.

Pondok pesantren Mansyaul Mubtadi' in adalah salah satu pondok pesantren yang ingin menyesuaikan diri dengan perkembangan teknologi informasi saat ini. Pondok pesantren Mansyaul Mubtadi' in ingin memanfaatkan teknologi informasi sebagai media untuk membantu proses pengelolaan pondok pesantren yang tadinya masih manual menjadi sistem informasi pengelolaan berbasis web.

Proses pengelolaan data di pondok pesantren Mansyaul Mubtadi' in saat ini masih bersifat tradisional dan manual. Dengan proses pengelolaan tersebut memunculkan banyak permasalahan yaitu: profil pondok pesantren belum terinformasikan dengan baik, sistem rekap data santri masih menggunakan kertas, terjadi penumpukan dokumen dalam ruangan, sulitnya melakukan pencarian data santri, dan pelaporan data yang rumit serta tidak rapih.
Berdasarkan latar belakang diatas maka dibutuhkan sebuah inovasi pengembangan sistem informasi pengelolaan pondok pesantren berbasis web yang diharapkan dapat membantu dalam proses pengelolaan pondok pesantren menjadi lebih baik dan mudah untuk digunakan.

Berdasarkan latar belakang masalah diatas, maka peneliti dapat merumuskan permasalahan sebagai berikut:

1. Bagaimana merancang dan membuat sistem informasi pengelolaan pondok pesantren mansyaul Mubtadi' in berbasis web yang menarik dan mudah untuk digunakan?

2. Bagaimana langkah-langkah dalam proses pembuatan sistem informasi pengelolaan pondok pesantren Mansyaul Mubtadi' in?

3. Bagaimana cara meningkatkan kemampuan pengelola dan pengurus pondok pesantren Mansyaul Mubtadi' in dalam menggunakan teknologi komputer?

Batasan masalah dari penelitian ini adalah sebagai berikut:

1. Sistem informasi pengelolaan pondok pesantren Mansyaul Mubtadi' in ini dibuat dengan menggunakan bahasa pemrograman PHP dan database MySQL.

2. Sistem informasi pengelolaan pondok pesantren Mansyaul Mubtadi' in ini meliputi pembuatan profil pondok pesantren, kegiatan pondok pesantren, gallery photo, input data santri, pencarian data, dan pelaporan.

3. Metodologi yang digunakan dalam penelitian ini adalah RUP (Rational Unified Process).

Diharapkan hasil dari penelitian ini dapat menghasilkan sebuah aplikasi yang dapat 
membantu dalam proses pengelolaan Pondok Pesantren. Adapun tujuan penelitian yang ingin dicapai adalah sebagai berikut:

1. Untuk membuat Sistem informasi pengelolaan pondok pesantren Mansyaul Mubtadi' in menggunakan bahasa pemrograman PHP dan database MySQL

2. Untuk membuat suatu inovasi pengembangan sistem informasi pengelolaan pondok pesantren Mansyaul Mubtadi' in berbasis web.

3. Untuk dapat menerapkan RUP (Rational Unified Process) dalam pembuatan sistem informasi pengelolaan pondok pesantren Mansyaul Mubtadi' in.

Manfaat dari penelitian ini dapat dibagi ke dalam 3 kategori, yaitu:

1. Bagi Pengelola pondok pesantren Mansyaul Mubtadi' in

- Dapat membantu proses pengelolaan sistem informasi pondok pesantren menjadi lebih cepat dan mudah.

- Dapat membantu proses pelaporan data santri dan pelaporan kegiatan di pondok pesantren dengan rapih dan mudah.

- Dapat membantu proses pencarian data dengan cepat dan mudah.

2. Bagi Masyarakat

- Dapat membantu memberikan informasi mengenai kegiatan pondok pesantren.

- Dapat mempermudah dalam proses pendaftaran santri.

- Dapat membantu masyarakat dalam proses pencarian data santri.

\section{Bagi Pemerintah}

- Dapat mempermudah pemerintah dalam proses pendataan pondok pesantren.

- Dapat mempermudah proses pelaporan pondok pesantren ke pemerintah.

\section{METODE PENELITIAN}

Tahap awal dalam penelitian ini adalah dengan mempersiapkan dan membuat proposal penelitian. Dalam proposal penelitian berisi latar belakang mengapa penelitian ini akan dijalankan. Tinjauan pustaka mengenai penelitian-penelitan sebelumnya yang berhubungan dengan penelitian ini juga dibahas didalam proposal penelitian.

Dalam tahap perancangan aplikasi dibuat rancangan arsitektur aplikasi, rancangan arsitektur jaringan dan rancangan tampilan. Setelah rancangan selesai tahap selanjutnya adalah tahap pengembangan aplikasi. Dalam tahap pengembangan aplikasi alur proses penelitian mengikuti langkah-langkah yang terdapat pada metode RUP. Pengujian aplikasi dilakukan dalam setiap langkah. Hal ini sesuai dengan metode RUP.

Pada tahap akhir pengujian aplikasi, akan dilakukan implementasi prototype dengan menggunakan data yang telah diperoleh sebelumnya. Semua proses dari pembuatan proposal sampai implementasi hasil penelitian dirumuskan dalam pembuatan laporan penelitian. Laporan penelitian merupakan hasil akhir dalam penelitian ini.

Dalam tahapan Inception ini kebutuhan dikelompokan menjadi dua bagian, yaitu kebutuhan fungsional dan kebutuhan non-fungsional. Kebutuhan fungsional adalah jenis kebutuhan yang berisi proses-proses apa saja yang harus ada, proses apa saja yang nantinya akan dilakukan oleh sistem dan informasi apa yang akan dihasilkan oleh sistem.

Adapun kebutuhan fungsional dalam sistem informasi pengelolaan pondok pesantren ini adalah:

1. Menyediakan fungsi untuk login pengelola atau admin;

2. Menyediakan halaman informasi untuk masyarakat;

3. Menyediakan halaman untuk mengolah data oleh admin;

4. Menyediakan halaman untuk pencarian data;

5. Menyediakan halaman untuk pelaporan

Kebutuhan non-fungsional merupakan kebutuhan yang digunakan untuk mendukung suatu sistem informasi agar dapat dijalankan. Adapun kebutuhan non-fungsional yang digunakan dalam membangun sistem informasi pengelolaan pondok pesantren ini adalah kebutuhan pernagkat lunak dan kebutuhan perangkat keras.

Sebelum membangun sistem informasi pengelolaan pondok pesantren Mansyaul Mubtadi' in dirancanglah sebuah use case diagram sebagai model perancangan untuk membanun sebuah sistem informasi. Gambar 1 merupakan rancangan use case diagram dari penelitian yang akan dibuat ini. 
Use case diagram mendeskripsikan sistem, lingkungan dan relasi antara sistem dengan lingkungannya. Dalam sistem informasi yang dibuat aktor memiliki beberapa perlakuan umum yang dapat dilakukan.

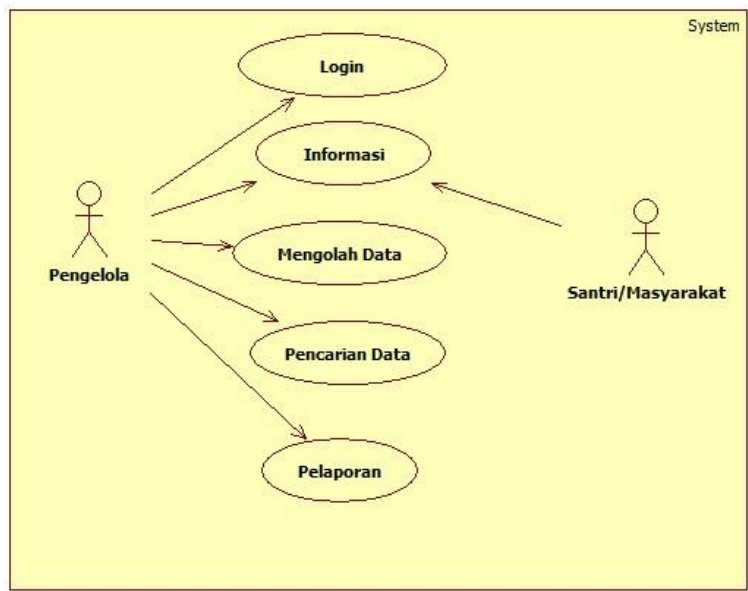

Gambar 1. Rancangan Use Case Diagram

Dalam gambar 1 tentang rancangan use case diagram terdapat dua aktor yaitu pengelola dan santri. Pengelola dapat mengakses halaman login, halaman informasi, halaman mengolah data, halaman pencarian data, dan halaman pelaporan. Sementara Santri hanya bias mengakses halaman informasi.

Tahap ellaboration merupakan tahap kedua setelah inception dalam metode RUP (Rational Unified Process). Tahap ellaboration digunakan untuk menentukan activity diagram dari sistem yang dibangun. Tahap ini memandang sistem lebih dalam, menganalisis masalah utama yang sedang dikembangkan serta mulai mempersiapkan tahapan selanjutnya yaitu tahapan contruction.

Activity diagram merupakan gambaran aliran kerja suatu kejadian yang ada pada sistem informasi. Pada activity diagram ini menggambarkan proses yang berjalan di sistem yang dilakukan oleh pengguna dari awal membuka sistem sampai menutup sistem.

Pada gambar 2 digambarkan bahwa pengelola mengakses sistem kemudian akan muncul menu utama. Setelah itu menu utama dapat diakses lebih jauh setelah login

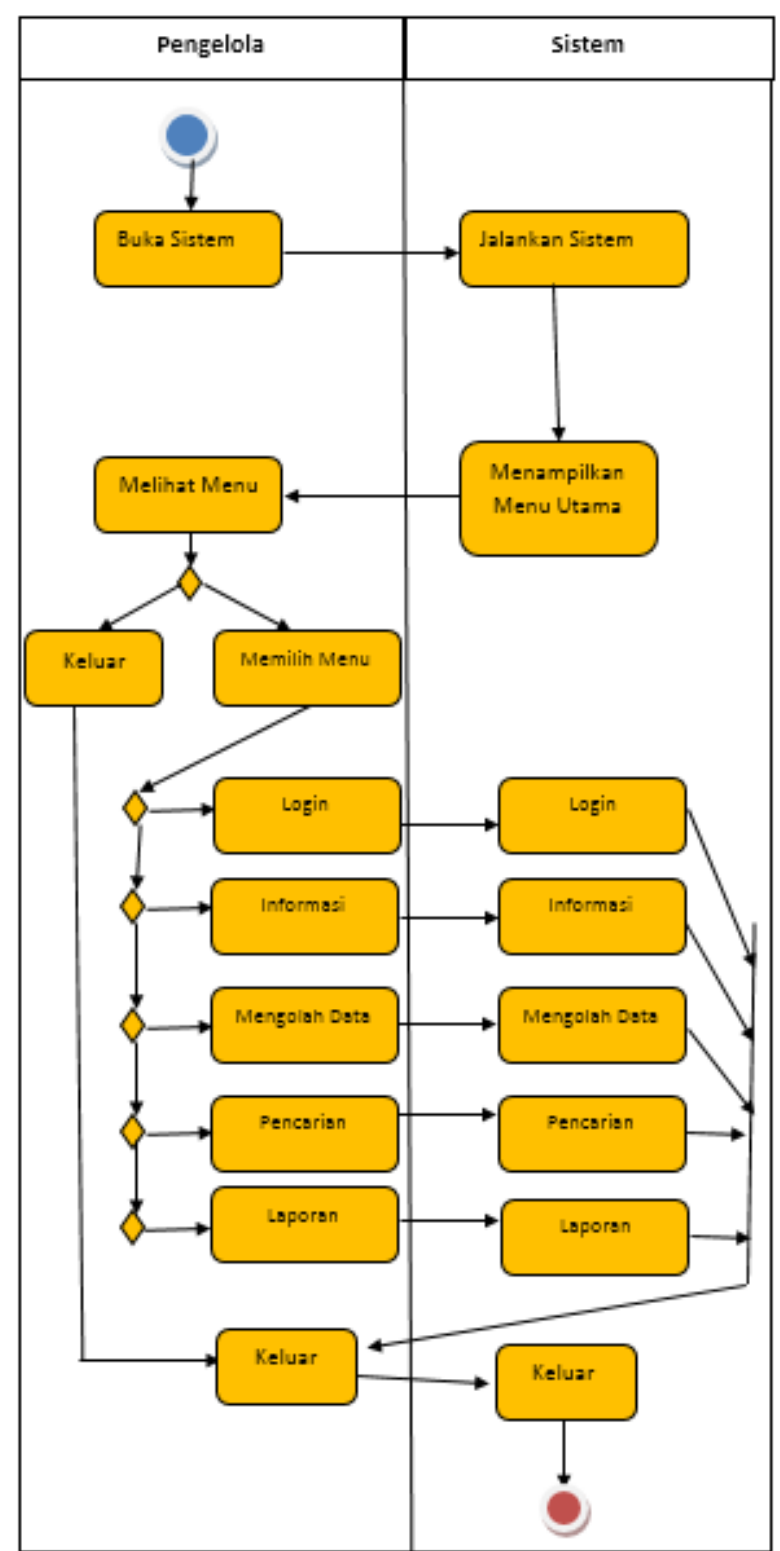

Gambar 2. Gambar Activity Diagram Menu Utama

Setelah menentukan activity diagram langkah selanjutnya adalah membuat class diagram. Class diagram menggambarkan suatu hubungan statis dari sebuah sistem..Adapun class diagram dari sistem yang akan dibangun dapat dilihat pada gambar 3 .

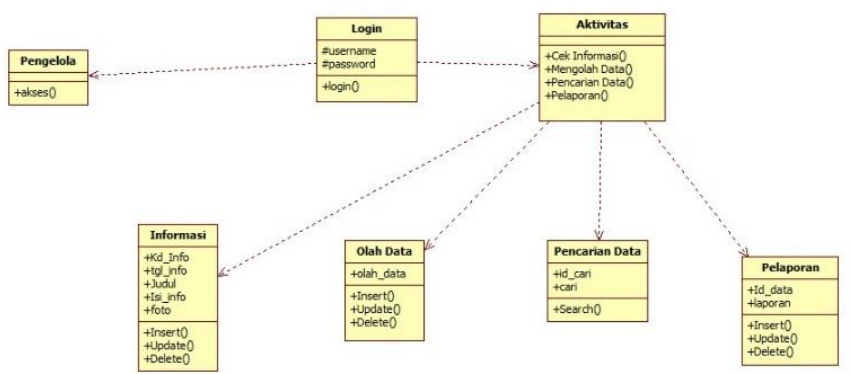

Gambar 3. Gambar Class Diagram Sistem 
Dari gambar 3 dapat dijeaskan bahwa user yang dapat mengakses aktivitas adalah user pengelola. Untuk dapat melakukan aktivitas user pengelola harus melakukan login terlebih dahulu.

Proses selanjutnya setelah membuat class diagram adalah membuat sequence diagram. Sequence diagram digunakan untuk menggambarkan rangkaian langkah-langkah yang dilakukan sebagai sebuah respon dari suatu kejadian untuk menghasilkan output. Adapun sequence diagram yang dirancang dari sistem informai ini dapat dilihat pada gambar 4 .

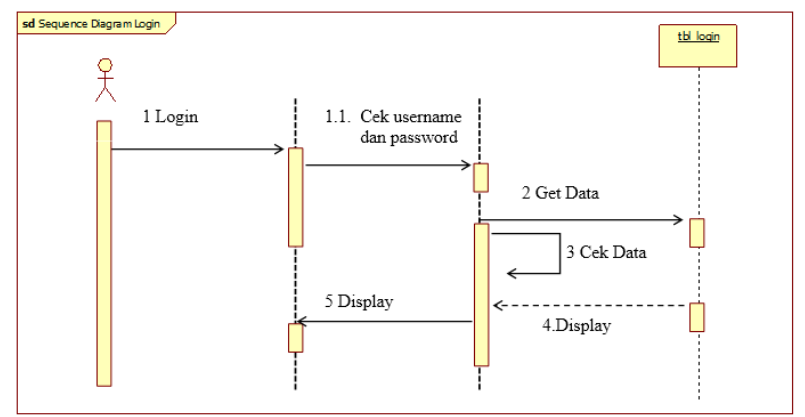

Gambar 4. Gambar Sequence Diagram Sistem

Gambar 4 menggambarkan alur proses yang terjadi pada sequence diagram login. Dimulai dari pengelola melakukan login, kemudian dilanjutkan dengan pengecekan username dan password, kemudian terjadi Get Data dan Cek Data jika benar dan sesuai maka akan masuk ke display.

Setelah tahapan Inception dan Elaboration dilakukan, maka selanjutnya akan dilakukan tahapan Construction dan Transition. Pada tahapan Construction akan lebih fokus pada hasil perancangan tampilan dan menu-menu yang diusulkan. Sementara itu, pada tahapan Transition lebih fokus pada proses pengujian dari aplikasi yang dirancang.

\section{HASIL DAN PEMBAHASAN}

Setelah mengalami sederetan proses iterasi, pada tahapan Construction ini sudah dapat menghasilkan suatu aplikasi. Halaman tampilan utama merupakan halaman awal yang pertama kali muncul ketika aplikasi dijalankan. Gambar 5 merupakan hasil dari halaman menu utama.

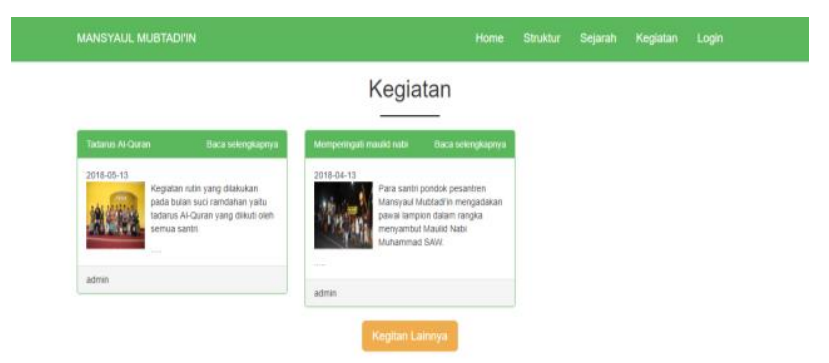

Gambar 5. Tampilan Menu Utama

Pada gambar 5 merupakan gambar tampilan halaman menu utama dari sistem informasi yang dibangun. Pada halaman menu utama terdapat sub menu informasi struktur, informasi sejarah, informasi kegiatan dan halaman login untuk pihak pengelola. Pemilihan warna background hijau didasarkan atas identitas pondok pesantren Mansyaul Mubtadi'in yang identik dengan warna hijau juga.

Pada gambar 6 merupakan gambar dari halaman informasi struktur pondok pesantren

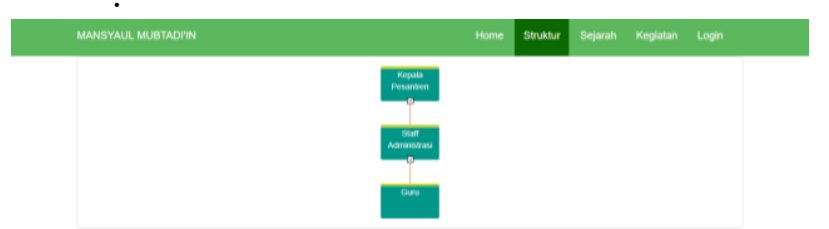

Gambar 6. Tampilan Informasi Struktur

Pada gambar 7 merupakan gambar dari halaman informasi sejarah berdirinya pondok pesantren Mansyaul Mubtadi' in.

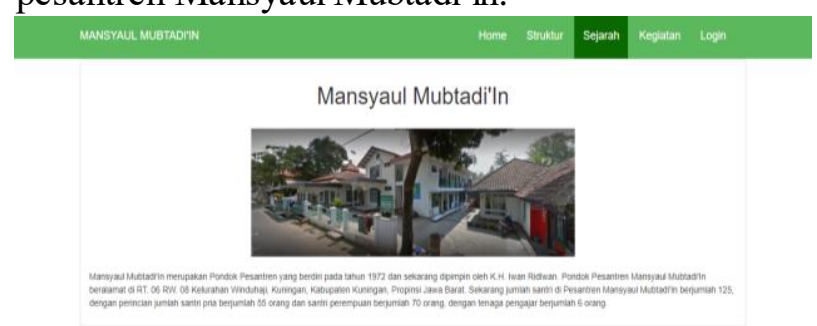

Gambar 7. Tampilan Informasi Sejarah

Pada gambar 8 merupakan gambar halaman tampilan login. Halaman tampilan login ini digunakan oleh pengelola admin untuk mengelola data yang ada di pondok pesantren. Pihak pengelola 
dapat memasukan username dan password yang sudah diberikan sehingga dapat masuk ke menu halaman utama sistem informasi.

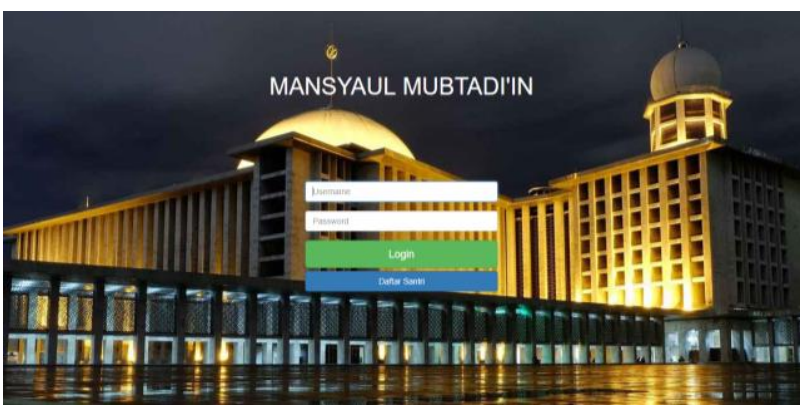

Gambar 8. Tampilan Halaman Login

Pada gambar 9 merupakan gambaran dari halaman admin. Halaman admin ini dapat muncul jika pihak pengelola dapat memasukan username dan password yang benar. Ketika pihak pengelola memasukan username dan password yang salah maka tidak dapat masuk ke halaman admin ini. Dibutuhkan data yang valid untuk dapat mengakses halaman admin ini.

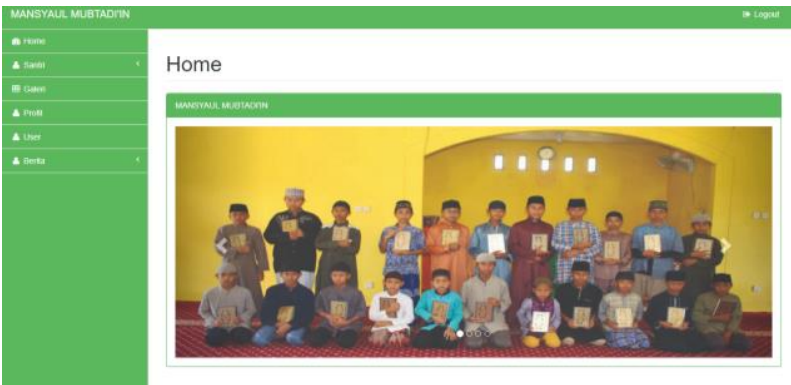

Gambar 9. Gambar Halaman Tampilan Admin

Pada gambar 10 merupakan gambar pengelolaan data santri. Pada halaman ini pihak pengelola dapat memasukan data santri, dapat merubah data santri dan dapat menghapus data santri.

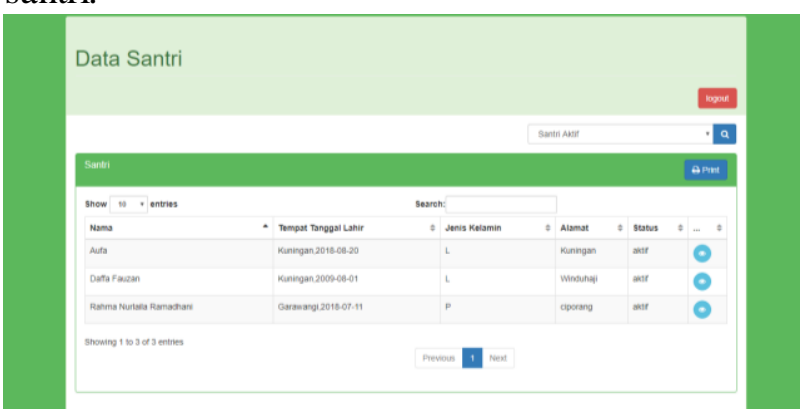

Gambar 10. Gambar Halaman Tampilan Santri

Tahap transition merupakan tahapan akhir dari proses RUP. Dalam tahapan ini lebih difokuskan pada masalah pengujian. Proses pengujian sendiri memiliki banyak jenis. Proses pengujian adalah proses mengeksekusi sistem informasi untuk menentukan apakah sistem yang dibangun sesuai dengan spesifikasi dan dapat berjalan sesuai dengan lingkungan yang diinginkan.

Tahap pengujian merupakan bagian penting dari kualitas sistem informasi yang dibangun dan mempresentasikan kajian pokok dari spesifikasi, perancangan, dan proses pengkodean. Pada penelitian ini dilakukan proses pengujian Black Box dan White Box.

Pengujian Black Box adalah proses pengujian aspek fundamental sistem informasi tanpa memperhatikan struktur logika internal perangkat lunak. Proses pengujian ini dilakukan untuk mengetahui apakah sistem informasi yang dibangun dapat berjalan dan berfungsi dengan benar. Hasil pengujian dapat dilihat pada Tabel 1 .

Tabel 1. Hasil Pengujian Black Box

\begin{tabular}{|c|c|c|c|c|}
\hline No & $\begin{array}{l}\text { Fungsi } \\
\text { yang di uji }\end{array}$ & Cara Menguji & $\begin{array}{l}\text { Hasil yang } \\
\text { diharapkan }\end{array}$ & $\begin{array}{l}\text { Hasil } \\
\text { yang } \\
\text { keluar }\end{array}$ \\
\hline 1 & Cek Login & $\begin{array}{l}\text { User } \\
\text { melakukan } \\
\text { Login dengan } \\
\text { memasukan } \\
\text { username dan } \\
\text { password yang } \\
\text { benar }\end{array}$ & $\begin{array}{l}\text { User dapat } \\
\text { masuk kedalam } \\
\text { halaman menu } \\
\text { utama aplikasi }\end{array}$ & $\begin{array}{l}\text { Sesuai } \\
\text { dengan } \\
\text { harapan } \\
\text { Valid }\end{array}$ \\
\hline 2 & Cek Login & $\begin{array}{l}\text { User } \\
\text { melakukan } \\
\text { Login dengan } \\
\text { memasukan } \\
\text { username dan } \\
\text { password yang } \\
\text { salah }\end{array}$ & $\begin{array}{l}\text { Muncul Pesan } \\
\text { Error "Pastikan } \\
\text { username dan } \\
\text { Password yang } \\
\text { dimasukan } \\
\text { Benar" }\end{array}$ & $\begin{array}{l}\text { Sesuai } \\
\text { dengan } \\
\text { harapan } \\
\text { Valid }\end{array}$ \\
\hline 3 & $\begin{array}{l}\text { Cek } \\
\text { Koneksi } \\
\text { Login } \\
\text { dengan } \\
\text { database }\end{array}$ & $\begin{array}{l}\text { Memasukan } \\
\text { username dan } \\
\text { password baru } \\
\text { kedalam } \\
\text { database, untuk } \\
\text { Login dengan } \\
\text { user baru }\end{array}$ & $\begin{array}{l}\text { User dapat } \\
\text { masuk dengan } \\
\text { username dan } \\
\text { password baru }\end{array}$ & $\begin{array}{l}\text { Sesuai } \\
\text { dengan } \\
\text { harapan } \\
\text { Valid }\end{array}$ \\
\hline 4 & $\begin{array}{l}\text { Cek Menu } \\
\text { Struktur }\end{array}$ & $\begin{array}{l}\text { User mengklik } \\
\text { menu struktur }\end{array}$ & $\begin{array}{l}\text { Menampilkan } \\
\text { menu struktur }\end{array}$ & $\begin{array}{l}\text { Sesuai } \\
\text { dengan } \\
\text { harapan } \\
\text { Valid }\end{array}$ \\
\hline 5 & $\begin{array}{l}\text { Cek Menu } \\
\text { Sejarah }\end{array}$ & $\begin{array}{l}\text { User mengklik } \\
\text { menu sejarah }\end{array}$ & $\begin{array}{l}\text { Menampilkan } \\
\text { menu sejarah }\end{array}$ & $\begin{array}{l}\text { Sesuai } \\
\text { dengan } \\
\text { harapan } \\
\text { Valid }\end{array}$ \\
\hline 5 & $\begin{array}{l}\text { Cek input } \\
\text { data santri }\end{array}$ & $\begin{array}{l}\text { User } \\
\text { memasukan } \\
\text { data santri }\end{array}$ & $\begin{array}{lr}\text { Data } & \text { santri } \\
\text { masuk } & \text { ke } \\
\text { database } & \end{array}$ & $\begin{array}{l}\text { Sesuai } \\
\text { dengan } \\
\text { harapan } \\
\text { Valid }\end{array}$ \\
\hline 6 & $\begin{array}{l}\text { Cek } \\
\text { Pencarian }\end{array}$ & $\begin{array}{l}\text { User } \\
\text { memasukan } \\
\text { data santri }\end{array}$ & $\begin{array}{l}\text { Ditemukan data } \\
\text { santri }\end{array}$ & $\begin{array}{l}\text { Sesuai } \\
\text { dengan } \\
\text { harapan } \\
\text { Valid }\end{array}$ \\
\hline
\end{tabular}




\section{KESIMPULAN}

Kesimpulan dari penelitian ini adalah sebagai berikut:

1. Dihasilkannya program sistem informasi pengelolaan pondok pesantren mansyaul Mubtadi' in berbasis website yang menarik dan mudah digunakan.

2. Dengan adanya sistem informasi pengelolaan pondok pesantren Mansyaul Mubtadi' in berbasis website ini dapat membantu dan mempermudah dalam proses pencatatan dan pencarian data.

3. Proses pelaporan data santri dapat diakses dengan mudah oleh pihak pengelola pondok pesantren

\section{SARAN}

Sesuai dengan permasalahan yang ada dan setelah perancangan aplikasi ini selesai, maka diberikan beberapa saran yang dapat digunakan dalam pengembangan aplikasi di masa mendatang. sebagai berikut:

Saran dari kegiatan penelitian ini adalah

1. Perlu segera dilakukan tahap implementasi dan pelatihan terkait sistem informasi pengelolaan pondok pesantren ini.

2. Perlu melakukan pengujian eksternal terhadap sistem informasi yang dibangun.

3. Perlu segera melakukan publikasi dan pembuatan laporan akhir dari kegiatan penelitian ini

\section{DAFTAR PUSTAKA}

Al Fatta, H. (2007). Analisis dan Perancangan Sistem Informasi untuk Keunggulan Bersaing Perusahaan dan Organisasi Modern. Yogyakarta : CV. Andi Offset.

Nugroho, Adi. 2005. "Analisis dan Perancangan Sistem Informasi dengan Metodologi Berorientasi Objek". Bandung: Informatika.

Presssman, R. S, 2011. "Softare Engineering : A Practitioners Approach", McGraw-Hill.

Rosa-Shalahuddin, A. S. M. 2013. Rekayasa Perangkat Lunak Terstruktur dan Berorientasi Objek. Bandung : Informatika.

Sridadi Bambang, 2009, Pemodelan dan Simulasi Sistem : Teori, Aplikasi dan Contoh Program Dalam Bahasa C, Bandung : Informatika Bandung.

Sutabri, Tata, S.Kom., MM., 2012. Analisis Sistem Informasi. Yogyakarta: Andi
Yakub. 2012. Pengantar Sistem Informasi, Yogyakarta: Graha Ilmu

\section{Biodata Penulis}

Tito Sugiharto,memperoleh gelar Sarjana Komputer (S.Kom), Jurusan Teknik Informatika STMIK AMIKOM Yogyakarta, lulus tahun 2008. Memperoleh gelar Magister Enggineering (M.Eng) Program Pasca Sarjana Magister Teknologi Informasi Universitas Gajah Mada Yogyakarta, lulus tahun 2014. Saat ini menjadi Dosen di Universitas Kuningan Jawa Barat. Saat ini juga menjabat sebagai Kaprodi S1 Teknik Informatika Fakultas Ilmu Komputer di Universitas Kuningan.

Siti Maesyaroh, M.Kom, memperoleh gelar Sarjana Komputer (S.Kom), Jurusan Teknik Informatika Universitas Kuningan. Memperoleh gelar Magister Komputer (M.Kom). Saat ini menjadi Dosen di Universitas Kuningan Jawa Barat. Saat ini juga menjabat sebagai Dosen tetap Yayasan di Teknik Informatika Fakultas Ilmu Komputer di Universitas Kuningan. 